\title{
Decomposition from legume and non-legume crop residues: Effects on soil organic carbon fractions under controlled conditions
}

\author{
Descomposición de restos de cultivos de leguminosas y no leguminosas: Efectos sobre las \\ fracciones de carbono orgánico del suelo bajo condiciones controladas \\ Decomposiçấo de resíduos da cultura de leguminosas e não leguminosas: Efeitos, em \\ condiçôes controladas, nas fraçôes de carbono orgânico do solo
}

\section{AUTHORS}

\section{Sá Pereira E. de ${ }^{1}$}

Duval M.E. 2,@

mduval@criba.edu.ar

Galantini J.A. ${ }^{3}$

@ Corresponding Author

${ }^{1}$ Agencia Extensión Rural INTA, Coronel Suárez (EEA

Bordenave). Sauce Corto $N^{\circ} 589$ Coronel Suárez, Buenos Aires Argentina.

\section{${ }^{2}$ CERZOS, Dpto.} Agronomía, Universidad Nacional del Sur (UNS)-CONICET. San Andrés 800,8000 , Bahía Blanca, Argentina.

\section{${ }^{3}$ Comisión}

Investigaciones Científicas (Bs. As.) CERZOS, Dpto. Agronomía Universidad Nacional del Sur (UNS)-CONICET. San Andrés 800,8000 , Bahía Blanca, Argentina.
Received: 02.03.2017 | Revised: 08.07.2017 | Accepted: 09.07.2017

\section{ABSTRACT}

Cover crop (CC) residues protect the soil from erosion and their permanence on the surface is largely influenced by their biochemical constituents. We performed a study under controlled conditions to investigate the dynamics of legume and non-legume $\mathrm{CC}$ residues decomposition and the transformations of the soil labile organic carbon fractions in the surface layer $(0-15 \mathrm{~cm})$. The experiment was carried out on a Typic Argiudoll (clay loam, $27.4 \mathrm{~g} \mathrm{~kg}^{-1}$ soil organic matter, $14 \mathrm{mg} \mathrm{kg}^{-1}$ extractable phosphorus and $6.5 \mathrm{pH})$ placed in undisturbed pots $\left(1570 \mathrm{~cm}^{3}\right)$ in a greenhouse under controlled conditions of temperature $\left(25 \pm 1{ }^{\circ} \mathrm{C}\right)$. We evaluated three $\mathrm{CC}$ species (oat, Avena sativa L.; vetch, Vicia sativa L.; Persian clover, Trifolium resupinatum L.) and a no-CC control (fallow). Shoot residues were applied on the soil surface at 5.4, 5.4 and $2.7 \mathrm{~g}$ dry matter (equivalent to 6, 6 and $3 \mathrm{Mg} \mathrm{ha}^{-1}$ for oat, vetch and clover, respectively) and incubated for 362-days (eight sampling times). The water content in the pots was maintained periodically by weight at $60 \%$ of soil water-holding capacity. The soil samples were analyzed for particulate organic carbon (POC), and total and soluble carbohydrates $(\mathrm{CHt}$ and $\mathrm{CHs}$, respectively). Oat and vetch residues decomposed faster than clover, with the decomposition rate constant $(\mathrm{k})$ values of $1.3,1.4$ and 1.9 year $^{-1}$, respectively. At the end of the experiment, POC concentration was lower in vetch $\left(1.83 \mathrm{~g} \mathrm{~kg}^{-1}\right)$ and clover $\left(1.96 \mathrm{~g} \mathrm{~kg}^{-1}\right)$ than in oat $\left(2.21 \mathrm{~g} \mathrm{~kg}^{-1}\right)$ and fallow $\left(3.00 \mathrm{~g} \mathrm{~kg}^{-1}\right)$, indicating a loss of $45-64 \%$ from their initial values. Soil $\mathrm{CHt}$ was influenced by residue quality, where the periods of greatest residue decay (vetch 21-59 days and oat 93-130 days) corresponded to higher soil CHt. Hence, this organic carbon fraction is sensitive to residue decomposition and can be indicators of changes in soil organic matter over short periods of time.

\section{RESUMEN}

Los cultivos de cobertura (CC) protegen al suelo de la erosión y su permanencia en el tiempo está influenciada en gran medida por su composición química. Se realizó un estudio en condiciones controladas para investigar la dinámica de descomposición de residuos de CC y las transformaciones de las fracciones orgánicas lábiles en la capa superficial del suelo (0-15 cm). El experimento se llevó a cabo en un Typic Argiudoll (franco arcilloso, 27,4 $\mathrm{g} \mathrm{kg}^{-1} \mathrm{de}$ materia orgánica del suelo, $14 \mathrm{mg} \mathrm{kg}^{-1}$ de fósforo extraíble y 6,5 depH) colocado sin disturbar en macetas $\left(1570 \mathrm{~cm}^{3}\right)$ en invernadero bajo condiciones controladas de temperatura $\left(25^{\circ} \pm 1^{\circ} \mathrm{C}\right.$ ). Se evaluaron tres especies de CC (avena, Avena sativa L.; veza, Vicia sativa $L$. y trébol, Trifolium resupinatum L.) y un control sin CC (barbecho). En la superficie del suelo, se aplicaron 5,4, 5,4 y 2,7 g de materia seca (equivalentes a 6, 6 y $3 \mathrm{Mg}^{\mathrm{ba} \mathrm{a}^{-1}}$ de avena, veza y trébol, respectivamente) y se incubaron durante 362 días (ocho fechas de muestreo). El contenido de agua en el suelo 
de las macetas fue mantenido al 60\% de la capacidad de retención de agua. En las muestras de suelo se determinó carbono orgánico particulado (POC), y carbohidratos totales y solubles (CHt y $C H$ s, respectivamente). Los residuos de avena y veza se degradaron más rápidamente que el trébol, con tasas de descomposición ( $k$ ) de 1,3, 1,4 y 1,9 $a_{\text {ños }}^{-1}$, respectivamente. Al final del experimento, la concentración de POC fue menor en el suelo con veza 1,83 $\left.\mathrm{g} \mathrm{kg}^{-1}\right)$ y trébol $\left(1,96 \mathrm{~g} \mathrm{~kg}^{-1}\right)$ que con avena $\left(2,21 \mathrm{~g} \mathrm{~kg}^{-1}\right)$ y barbecho $\left(3,00 \mathrm{~g} \mathrm{~kg}^{-1}\right)$, lo que indica una pérdida de 45-64\% de sus niveles iniciales. Los CHt fueron influenciados por la calidad de los residuos, donde los períodos de mayor descomposición de residuos (veza 21-59 dias y avena 93-130 días) coinciden con los mayores contenidos de CHt en el suelo. Por lo tanto, esta fracción de carbono orgánico es sensible a la descomposición de residuos y puede ser indicadores de cambios en la materia orgánica del suelo durante cortos periodos de tiempo.

\section{RESUMO}

Os resíduos de cobertura (CC) protegem o solo da erosão e a sua permanência na superfície do solo é largamente influenciada pelos seus constituintes bioquimicos. Realizou-se um estudo, em condiçôes controladas, para investigar a dinâmica da decomposição dos resíduos CC provenientes de leguminosas e não leguminosas e as transformaçôes das fraçôes de carbono lábeis na camada superficial do solo $(0-15 \mathrm{~cm})$. O ensaio foi realizado em estufa, em condiçôes controladas de temperatura $\left(25 \pm 1^{\circ} \mathrm{C}\right.$ ), num Typic Argiudoll (franco argiloso, com 27,4 $\mathrm{g} \mathrm{kg}^{-1}$ de matéria orgânica, $14 \mathrm{mg} \mathrm{kg}^{-1}$ de fósforo extraível e pH 6,5) que foi colocado, sem o perturbar, em vasos $\left(1570 \mathrm{~cm}^{3}\right)$. Avaliaram-se três espécies de CC (aveia, Avena sativa L.; ervilhaca, Vicia sativa L. e trevo-da-Pérsia, Trifolium resupinatum L.) e um controlo sem CC (pousio). Na superfície do solo aplicaram-se 5,4; 5,4 e 2, $7 \mathrm{~g}$ de matéria seca (equivalente a 6; 6 e Mg ha-1 de aveia, ervilhaca e trevo-da-Pérsia, respetivamente) e incubaram-se durante 362 dias (oito datas de amostragem). Nos vasos, o conteúdo em água no solo foi mantido a $60 \%$ da sua capacidade de retenção de água. Nas amostras de solo foram analisados o carbono orgânico particulado (POC) e os hidratos de carbono totais e solúveis (CHt e CHs, respetivamente). Os residuos de aveia e ervilhaca decompóem-se mais rapidamente do que os de trevoda-Pérsia, com valores de taxa de decomposição constante $(k)$ de 1,3; 1,4 e 1,9 ano ${ }^{-1}$, respetivamente. No final do ensaio, a concentração de POC era mais baixa nos solos com ervilhaca $\left(1,83 \mathrm{~g} \mathrm{~kg}^{-1}\right)$ e trevo-da-Pérsia $\left(1,96 \mathrm{~g} \mathrm{~kg}^{-1}\right)$ do que nos solos com aveia $\left(2,21 \mathrm{~g} \mathrm{~kg}^{-1}\right)$ e em pousio $\left(3,00 \mathrm{~g} \mathrm{~kg}^{-1}\right)$, indicando uma perda de 45-64\% em relação aos valores iniciais. Os valores de CHt no solo foram influenciados pela qualidade dos resíduos, onde os periodos de maior decomposiçâa destes (ervilhaca: 21-59 dias e aveia: 93-130 dias) correspondem às maiores concentraçôes de CHt no solo. Assim, esta fração de carbono orgânico é sensivel à decomposição do resíduo e pode ser um indicador das alteraçôes na matéria orgânica do solo durante curtos periodos de tempo.

\section{Introduction}

Cover crops (CC) are essential in the Pampas region for preventing soil degradation caused by annual summer crops, which leave the soil unprotected during the mild winter (RimskiKorsakov et al. 2015). Cover crops may thus influence soil organic carbon (SOC) content by providing additional residue carbon to soil (Wang et al. 2010). Nevertheless, reported effects of CC on SOC contents are inconsistent and range from losses (Mazzoncini et al. 2011) to gains (Duval et al. 2016). In a global meta-analysis, Poeplau and Don (2015) found a mean annual sequestration rate of $0.32 \pm 0.08 \mathrm{Mg} \mathrm{SOC} \mathrm{ha-1}^{-1}$, but they were unable to explain the scatter by environmental parameters or the functional type of CC (legume/non-legume). These inconsistent results are probably due to the soil's natural heterogeneity (Wander and Traina 1996), which may render sampling rather unreliable for soil variability estimations. It has been shown, however, that under field conditions, carbon sequestration varies among species and can thus be optimized by the choice of CC species. 
Soil organic fractions such as carbohydrates $(\mathrm{CH})$ or particulate organic carbon (POC) are more sensitive than SOC because of the changes induced by crop management practices (Galantini et al. 2004; Duval et al. 2014). These fractions are considered reliable indicators of soil quality over short periods of time (Kuo et al. 1997). Soluble carbohydrates in hot water $(\mathrm{CHs})$ represent a highly labile carbonaceous fraction of the total carbohydrates $(\mathrm{CHt})$ and they correspond to one of the most important pools of labile carbon of both plant and microbial origin (Ghani et al. 2003). In general, $\mathrm{CH}$ show a higher temporal variability as compared with SOC because of changes in soil humidity, temperature and precipitation (Hevia et al. 2003), as well as the quantity and quality of plant residues added to the soil. In this respect, most research studies have evaluated the dynamics of residue decomposition, but not the changes produced in labile soil organic fractions. It will be hence essential for farmers to have information about the overall effects of CC on production systems so they are able to adopt the most appropriate CC (Scholberg et al. 2010). For this reason, our hypothesis was that the decomposition of different $\mathrm{CC}$ residues modifies the dynamics of labile soil organic fractions according to the characteristics of those residues. However, multiple effects can modify residues decomposition under field decomposition, and shoot tissues are not subjected to equivalent conditions in soils (soil, temperature and moisture, among others) (Rasse et al. 2005). The objective of this study was to evaluate the decomposition dynamics of different $\mathrm{CC}$ residues and the transformations of the labile forms of SOC under controlled conditions of humidity and temperature through an incubation experiment.

\section{Materials and methods}

\subsection{Soil and residue materials}

The soil used in this study was collected from the southwest of Buenos Aires province $\left(37^{\circ} 23^{\prime} \mathrm{S}, 62^{\circ} 11^{\prime} \mathrm{W}\right)$. It was classified as a Typic
Argiudoll (clay loam) (Soil Survey Staff 2010), with $27.4 \mathrm{~g} \mathrm{~kg}^{-1}$ soil organic matter, $14 \mathrm{mg} \mathrm{kg}^{-1}$ extractable phosphorus and $6.5 \mathrm{pH}$ (soil:water ratio $=1: 2.5)$, and an Ap-BA-Bt-BC-C horizon sequence.

The soil and plant samples were collected from experimental field plots sown with winter $\mathrm{CC}$ of oat (Avena sativa L.), vetch (Vicia sativa L.) and Persian clover (Trifolium resupinatum L.); a control treatment was used (fallow without a CC), which was kept weed-free with herbicide applications. The experiment was established on $150 \mathrm{~m}^{2}$ plots in a randomized block design with four treatments and three replications. On 15 October 2007, eight undisturbed soil samples were taken on each plot from the top $15 \mathrm{~cm}$ using an extractor with a 10$\mathrm{cm}$ diameter cylinder that was placed on the threepoint linkage of a tractor. A $20 \mathrm{~cm}$ high PVC pipe was placed inside the sampling cylinder and filled with $15 \mathrm{~cm}$ of undisturbed soil.

Cover crop biomass samples were collected at the flowering stage (15 October) from $0.5 \mathrm{~m}^{2}$ areas on the same plot where the soil samples were collected. They were cut at ground level, and dried until constant weight in a forcedair oven at $60^{\circ} \mathrm{C}$. Half the $\mathrm{CC}$ shoot material was analyzed for the biochemical properties described below, and half was reserved for the pots.

2.2. Experimental design, soil sampling and
analysis

A pot experiment was performed in a greenhouse. The plastic pots were $10 \mathrm{~cm}$ in diameter, $20 \mathrm{~cm}$ in high and $1570 \mathrm{~cm}^{3}$ in volume; in each plot, $1.5 \mathrm{~kg}$ soil was packed to a similar bulk density to that in the field. Water-holding capacity was measured as the gravimetric water content of saturated soil that was submitted to $33 \mathrm{kPa}$ using a pressure plate extractor (Soil Moisture Equipment Co., Santa Barbara, California) (Klute 1986). Ninety-six samples (pots) were placed at random in a greenhouse under controlled conditions of temperature $\left(25 \pm 1^{\circ} \mathrm{C}\right)$. The pots were periodically weighed to maintain the water content at $60 \%$ of soil water-holding capacity.

The basic treatment design consisted of 1) a fallow (24 pots) in which no CC residue was 
applied and; 2) pots in which oven-dried CC residues were added; this latter treatment was conducted for each CC species (24 pots for each specie). The residues of oat, vetch, and clover were cut into 2- to $3-\mathrm{cm}$ particles and placed on soil surface, applying $5.4 \mathrm{~g}$ dry matter (DM) of oat, $5.4 \mathrm{~g}$ of vetch and $2.7 \mathrm{~g}$ of clover at a biomass rate of 6,6 and $3 \mathrm{Mg} \mathrm{ha}^{-1}$, respectively. This rate was equivalent to that observed in the experimental field plots.

\subsection{Initial quality of $\mathrm{CC}$ residue}

The initial DM, carbon, nitrogen and biochemical composition (lignin, cellulose, hemicellulose and nonstructural carbohydrates [NSC]) of the residues were determined. Carbon was measured by dry combustion (LECO Carbon analyzer, LECO Corporation St. Joseph, MI, USA), total nitrogen was calculated through Kjeldahl's method (Bremner 1996) and the biochemical composition through the sequential method developed by Van Soest et al. (1991) (Table 1).

\subsection{Soil analysis}

Three pots were destructively sampled from each treatment on days 0 (referred to as the initial day), 21, 59, 93, 130, 201, 270 and 362. There were three replicates for each treatment, which resulted in a total of 96 pots (four treatments $x$ eight sampling times $\times$ three replicates).

Weight loss of $\mathrm{CC}$ residue was determined on each day for each of the three pots by carefully collecting the biomass residues from each treatment. To minimize the effect of soil contamination, the residual residue weight was calculated on an ash-free basis by determining the ash content $\left(550^{\circ} \mathrm{C}\right)$ in a 1 -g subsample from each pot. This procedure was performed to avoid overestimation caused by soil particles attached to the material, which increased as residual matter decreased. The percent of remaining $\mathrm{DM}$ at each sampling time was calculated as: remaining DM $(\%)=$ (amount of residue at each sampling time/amount of residue at the start) $\times 100$. The soil samples were divided into two

Table 1. Dry matter and quality of cover crop residues used in the experiment

\begin{tabular}{lcccccccc}
\multicolumn{1}{r}{$\begin{array}{c}\text { Cover } \\
\text { crops }\end{array}$} & C & N & NSC & Hemi & Cell & Lignin & LIG:N & C:N \\
\cline { 1 - 5 } Vetch & $397 \mathrm{a}$ & $42 \mathrm{a}$ & $67 \mathrm{c}$ & $657 \mathrm{a}$ & $215 \mathrm{a}$ & $61 \mathrm{~b}$ & $3.7 \mathrm{a}$ & $9 \mathrm{~b}$ \\
\hline Clover & $425 \mathrm{a}$ & $32 \mathrm{~b}$ & $100 \mathrm{~b}$ & $571 \mathrm{~b}$ & $194 \mathrm{a}$ & $135 \mathrm{a}$ & $4.1 \mathrm{a}$ & $13 \mathrm{~b}$ \\
\hline Oat & $424 \mathrm{a}$ & $21 \mathrm{~b}$ & $201 \mathrm{a}$ & $497 \mathrm{~b}$ & $209 \mathrm{a}$ & $93 \mathrm{ab}$ & $2.9 \mathrm{a}$ & $20 \mathrm{a}$ \\
\hline
\end{tabular}

C: carbon; N: nitrogen; Cell: cellulose; Hemi: hemicelluloses; NSC: nonstructural carbohydrates; LIG:N: lignin:nitrogen ratio; C:N: carbon:nitrogen ratio. Different letters in each column indicate significant differences among cover crop residues $(P<0.05)$.

layers (0-5 and 5-15 cm); they were air-dried and sieved $(2000 \mu \mathrm{m})$ to determine SOC fractions.

The samples were physically fractionated by wetsieving as described by Galantini et al. (2004). Briefly, about $50 \mathrm{~g}$ of soil and $100 \mathrm{~mL}$ of water was added together with 10 glass beads; they were then shaken for 16 hours at $40 \mathrm{rpm}$ and passed through a $105-\mu \mathrm{m}$ sieve. Through this procedure, the coarse $(105-2000 \mu \mathrm{m})$ and fine $(0-105 \mu \mathrm{m})$ fractions were obtained. The quantity of POC in the coarse fraction was determined by dry combustion with an automatic SOC analyzer (LECO Carbon analyzer, LECO Corporation St.
Joseph, MI, USA). The values were expressed as a percentage of the soil, using the value of the coarse fraction determined for each sample. Total $(\mathrm{CHt})$ and soluble $(\mathrm{CHs})$ carbohydrates were extracted from the soil samples by means of two procedures (Puget et al. 1999). An acid hydrolysis was performed to determine $\mathrm{CHt}$, as follows: $1 \mathrm{~g}$ of soil sample was treated with $10 \mathrm{~mL}$ of $\mathrm{H}_{2} \mathrm{SO}_{4} 0.5 \mathrm{~mol} \mathrm{~L}^{-1}$ and heated at $80{ }^{\circ} \mathrm{C}$ for 24 hours. To determine $\mathrm{CHs}, 1 \mathrm{~g}$ of soil sample was suspended in $10 \mathrm{~mL}$ of distilled water and heated at $80{ }^{\circ} \mathrm{C}$ for 24 hours; hydrolysis was attained by adding $\mathrm{H}_{2} \mathrm{SO}_{4}$ to obtain a $0.5 \mathrm{~mol} \mathrm{~L}^{-1}$ concentration, as in the dilute acid hydrolysis 
procedure. After extraction, each suspension was centrifuged at $4000 \mathrm{rpm}$ for 15 minutes. Carbohydrate contents were determined using the phenol-sulphuric acid spectrophotometric method with glucose standard curve.

\subsection{Statistical analysis}

A one-way analysis of variance (ANOVA) was used to test the differences in the quality of $C C$ residues. A two-way ANOVA tested whether $\mathrm{POC}, \mathrm{CHs}$ and $\mathrm{CH}$ t varied significantly among types of residues with sampling time. The mean test values were compared using the least significant difference with a significance level of 0.05 to get significant difference. All data were analyzed using Infostat statistical software (Di Rienzo et al. 2013).

\section{Results and discussion}

\subsection{Quality and decomposition of CC}

The chemical composition of CC residues varied widely among residues (Table 1). Residue quality (nitrogen, NSC, hemicelluloses and lignin) differed substantially with respect to the C:N ratios; on the other hand, cellulose and carbon concentrations and LIG:N ratio were similar for oat and legumes (vetch and clover) (Table 1).

The dynamics of oat, vetch and clover residues in the pots throughout the study period (Figure 1) was best described by a negative exponential equation, coinciding with reports from the literature reviews (Quemada 2005; Parton et al. 2007). The amount of residue measured in each sampling time on the soil surface is directly affected by the inherent factors governing decomposition rates (Li et al. 2016). In our study, such factors are represented by the $\mathrm{C}: \mathrm{N}$ ratios of the residues, which were higher in oat $(C: N=20)$ than in legumes ( $\mathrm{C}: \mathrm{N}=9$ for vetch and 13 for clover). Loss differences among oat, vetch and clover residues varied with time. The residual matter of oat, vetch and clover was $73 \%, 59 \%$ and $78 \%$ after 21 days; it decreased to $48 \%$, $39 \%$ and $61 \%$ of their initial biomass after 100 days and it reached $21 \%, 12 \%$ and $16 \%$ after 362 days, with a decomposition rate constant $(\mathrm{k})$ of 1.3, 1.4 and 1.9 year $^{-1}$, respectively (Figure 1). Decomposition rates for cereal residues reported in the literature varied from 1.8 to 11.0 year $^{-1}$, and for legumes from 0.4 to 3.0 year $^{-1}$ (Douglas and Rickman 1992; Schomberg et al. 1994).

Different patterns were observed in decomposition dynamics when the results were analyzed for each type of residue, mainly in the initial stage of decay, where high quality residues (e.g. vetch with a low $\mathrm{C}: \mathrm{N}$ ratio) increased the decomposition rate (Table 1, Figure 1). In the first sampling period (0-21 days) the decomposition of vetch residue was faster than oat and clover residues due to its lower lignin and higher nitrogen contents and, consequently, lower C:N ratios (Table 1). The lignin content is associated with residue resistance to decomposition more than any other single organic component, and its importance is equivalent to the $\mathrm{C}: \mathrm{N}$ ratio (Tian et al. 1995). Thus, a low lignin and high cellulose content may indicate that the initial residue quality is high in terms of potential nutrient mineralization. In the case of clover, initial decomposition would be slower as a result of poor residue quality, which is caused by a larger proportion of stems with a high content of lignified tissue at the time of removal (Table 1, Figure 1). This result suggests a physical protection of the easily decomposable carbon by high lignin concentration, which is consistent with reports by Ambus and Jensen (1997). After the initial rapid decomposition, there is a period (130 to 201 days) when the average decay rate is fast both for oat and clover, and tends to equal that of vetch. High decomposition rates of oat residues in the field were also observed by Moraes Sá and Lal (2009) in a 107- to 133-days period.

Throughout the 362-day experiment, vetch residues always showed a faster decomposition rate, with a $40 \%$ DM decrease 30 days after residue incorporation into the pots. Permanence of oat residues was longer, for even after 130 days there still remained $45 \%$ of the initial residue input; this stresses the idea that a lower $\mathrm{N}$-content and a higher $\mathrm{C}: \mathrm{N}$ ratio must have 
hindered degradation (Table 1, Figure 1). When Acosta (2009) worked with decomposition bags of oat and vetch residues on a field; he found that $50 \%$ decomposition only occurred after 164 days for oat and 49 for vetch. Clover residues showed intermediate decomposition rates when compared with oat and vetch residues, with intermediate values for $\mathrm{N}$ and the $\mathrm{C}: \mathrm{N}$ ratio (Table 1). The chemical compositions of crop residues is important in determining their decomposition pattern. Lupwayi et al. (2004) found a negative relationship between decomposed DM and its nitrogen, but a positive one with its $\mathrm{C}: \mathrm{N}$ ratio.
Although residual DM exponentially decreased and showed changes among $\mathrm{CC}$ during the experiment, the final values ranged from 12 to $21 \%$ of the original residue input (Figure 1 ). However, these results will help determine the best management practices for $\mathrm{CC}$ to protect the soil from erosion (Moraes Sá and Lal 2009). In fact, the maximum period between CC suppression and summer crop sowing could be up to 90 to 100 days (Carfagno et al. 2013; Duval et al. 2015), where the $61 \%$ clover, $48 \%$ oat and $39 \%$ vetch residues would still be present, thereby ensuring soil protection.
Oat

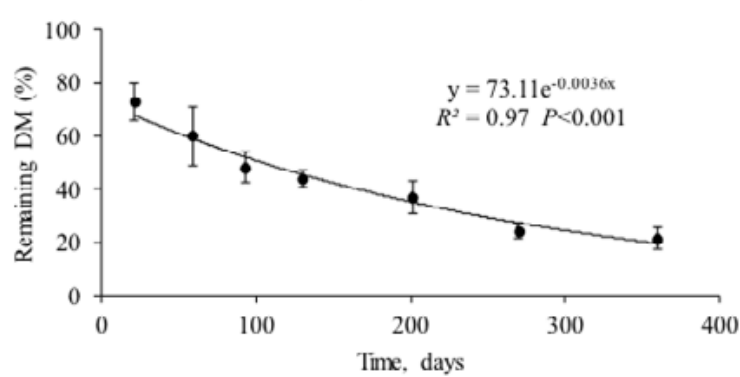

Vetch

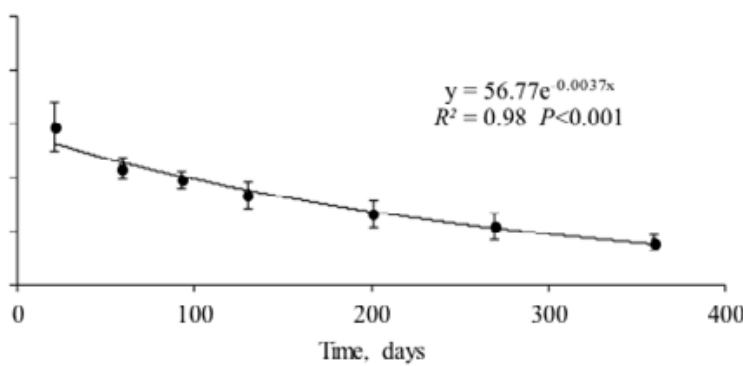

Clover

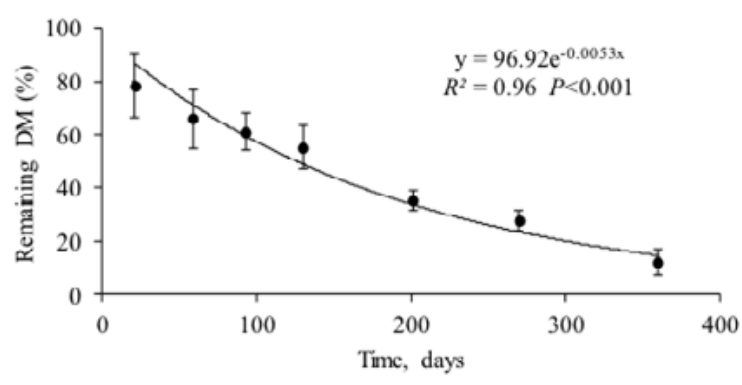

Figure 1. Decomposition dynamics of organic matter over 362 days for the different cover crops. The vertical bars represent \pm one standard deviation $(n=3)$.

\subsection{Soil organic fractions}

Concentration of POC in soil was influenced by both $\mathrm{CC}$ residues and sampling time (Figure 2 and 3). At the start of incubation (day 0), POC concentration did not differ among treatments. The initial values were, 4.74, 5.07, 4.60 and $5.47 \mathrm{~g} \mathrm{~kg}^{-1}$ for, oat, vetch, clover and fallow, respectively (Figure 3 ). Concentration of POC in the topsoil $(0-5 \mathrm{~cm})$ decreased over time throughout the experiment for the $\mathrm{CC}$ and fallow treatments. The fastest decomposition was observed in soils under vetch. Despite residue input (6 $\left.\mathrm{Mg} \mathrm{ha}^{-1}\right)$, this treatment showed lower POC concentration than the fallow treatment.
On day 362, POC concentration was the lower in vetch $\left(1.83 \mathrm{~g} \mathrm{~kg}^{-1}\right)$ and clover $\left(1.96 \mathrm{~g} \mathrm{~kg}^{-1}\right)$ than in oat $\left(2.21 \mathrm{~g} \mathrm{~kg}^{-1}\right)$ and fallow $\left(3.00 \mathrm{~g} \mathrm{~kg}^{-1}\right)$. With regard to the initial values, the approximate $\mathrm{POC}$ loss was 64, 57, 53 and 45\% for vetch, clover, oat and fallow, respectively (Figure 3 ). The mean POC decomposition rate constant (k) was 0.396 year $^{-1}$ and ranged from 0.288 to 0.540 year $^{-1}$ (Figure 2). The decrease in POC throughout the experiment indicated a substantial decomposition of the added residues (Figure 1). A large input of easily decomposed organic materials to the soil causes a rapid increase in respiration and microbial biomass (Bastida et al. 2008), which is most likely due to the utilization of the easily 
available organic compounds. The presence of easily available substrates also stimulates the decomposition of more recalcitrant materials, known as priming (Kuzyakov 2010; Duval et al. 2016). This may also be the case in our study.
With regard to clover, the lowest amount was applied at a more advanced stage of maturity; this may have decreased the decomposition rate and increased variability.
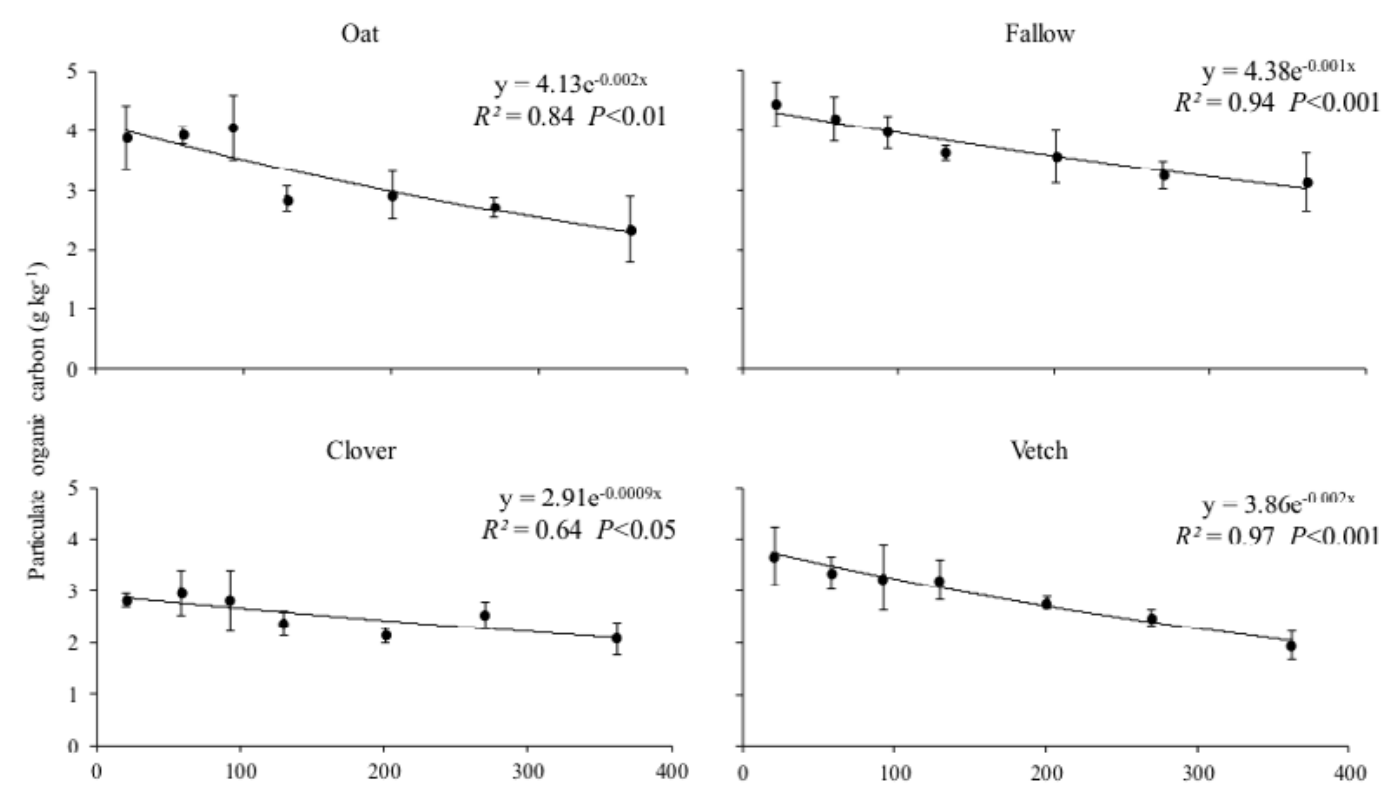

Vetch

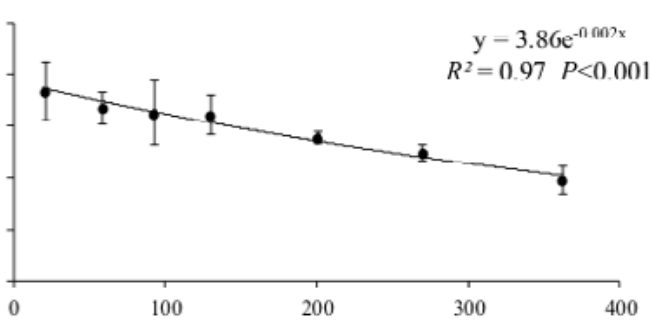

Time, days

Figure 2. Dynamics of particulate organic carbon $(\mathrm{POC})$ at the $0-5 \mathrm{~cm}$ depth under different treatment. The vertical bars represent \pm one standard deviation $(n=3)$.

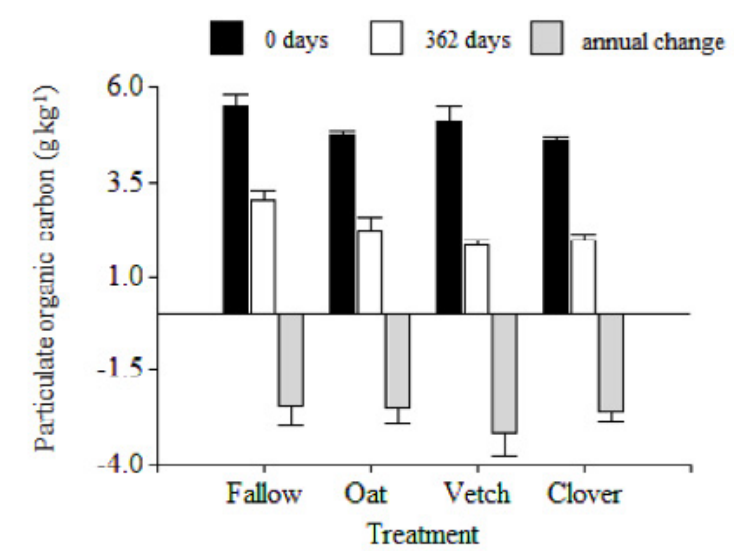

Figure 3. Particulate organic carbon at the start ( 0 days) and at the end ( 362 days) of the experiment for the $0-5 \mathrm{~cm}$ depth under different treatments. Bars represent the standard error $(n=3)$. 
Changes in total $(\mathrm{CHt})$ and soluble $(\mathrm{CHs})$ content in the fallow soil showed a similar trend to that in POC decomposition (Figure 4), revealing that these materials are readily available by microorganisms as substrate and become exhausted over time. However, $\mathrm{CH}$ and $\mathrm{CH}$ contents across the different $\mathrm{CC}$ increased and decreased throughout the experiment. These changes would be associated with residue transformation (input to the soil) and the use of the most labile materials by the soil biota output from the soil, where the quality of the material and $\mathrm{N}$-availability are important regulators (Moraes Sá et al. 2014).

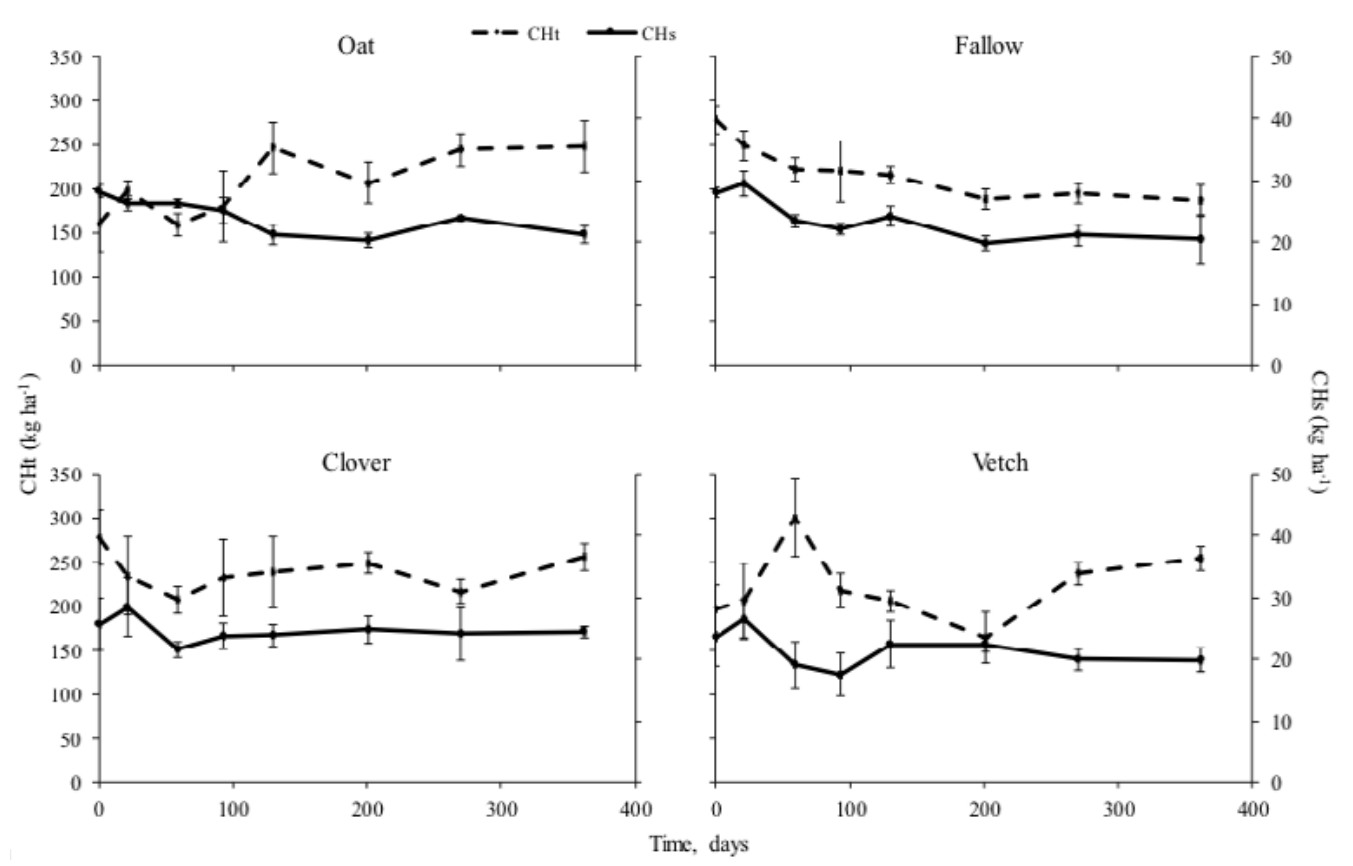

Figure 4. Dynamics of total $(\mathrm{CHt})$ and soluble $(\mathrm{CHs})$ carbohydrate contents at the $0-5 \mathrm{~cm}$ depth under different treatments. The vertical bars represent \pm one standard deviation $(n=3)$.

Several studies have documented the impact of land-use changes on soil CH (Duval et al. 2013; Ćirić et al. 2016) but very few have addressed the influence of residue decomposition on these labile fractions. Assuming that $\mathrm{CHt}$ decomposition in the fallow soil was similar to that in soils under $\mathrm{CC}$, the decay of initial $\mathrm{CHt}$ was calculated and it would be possible to estimate the input from the CC residues.

Figure 5 illustrates the estimations of $\mathrm{CHt}$ content in the fallow soil (line with square), of $\mathrm{CHt}$ in the treatment with residues (line with diamond) and the difference between both (line with triangle), which represents $\mathrm{CHt}$ from residue decomposition. In the case of oat, the input of carbonaceous material to the soil $\mathrm{CHt}$ is delayed; for vetch, instead, there are two important points in time: one of them at the beginning of the decomposition and the other one at the end of the period considered (Figure $5)$. These results coincide with those found by Duval et al. (2013), who concluded that much of the variability shown by $\mathrm{CH}$ t under no-tillage is associated with the different types of plant residues. When $\mathrm{CH}$ is extracted, other pools of labile nutrients are also extracted along with carbon (Ghani et al. 2003). It is hence suggested that a $\mathrm{CH}$ increase would also indicate an increase of other labile organic pools of nutrients such as nitrogen. In our study, a rise in soil $\mathrm{CHt}$ was observed for vetch after 21 days and for oat after 130 days, which correspond to the periods of high residue decomposition for both species (Figures 1 and 5). These results are consistent with those observed under field conditions, where vetch released up to $32 \%$ of the $\mathrm{N}$ accumulated in the residues during the first 30 
days, causing soil available N-levels to vary from 35 to $130 \mathrm{~kg} \mathrm{ha}^{-1}$ (Sá Pereira et al. 2014). From a crop production perspective, these results help to better understand the dynamics of nutrient release and their implication in improving synchrony between soil nutrient supply and the cash crop demand, and thus in reducing the environmental risk of nutrient leaching or runoff into waterways. Our results demonstrate that $\mathrm{CHt}$ is sensitive to residue decomposition and can be an indicators of changes in soil organic matter over short periods of time.
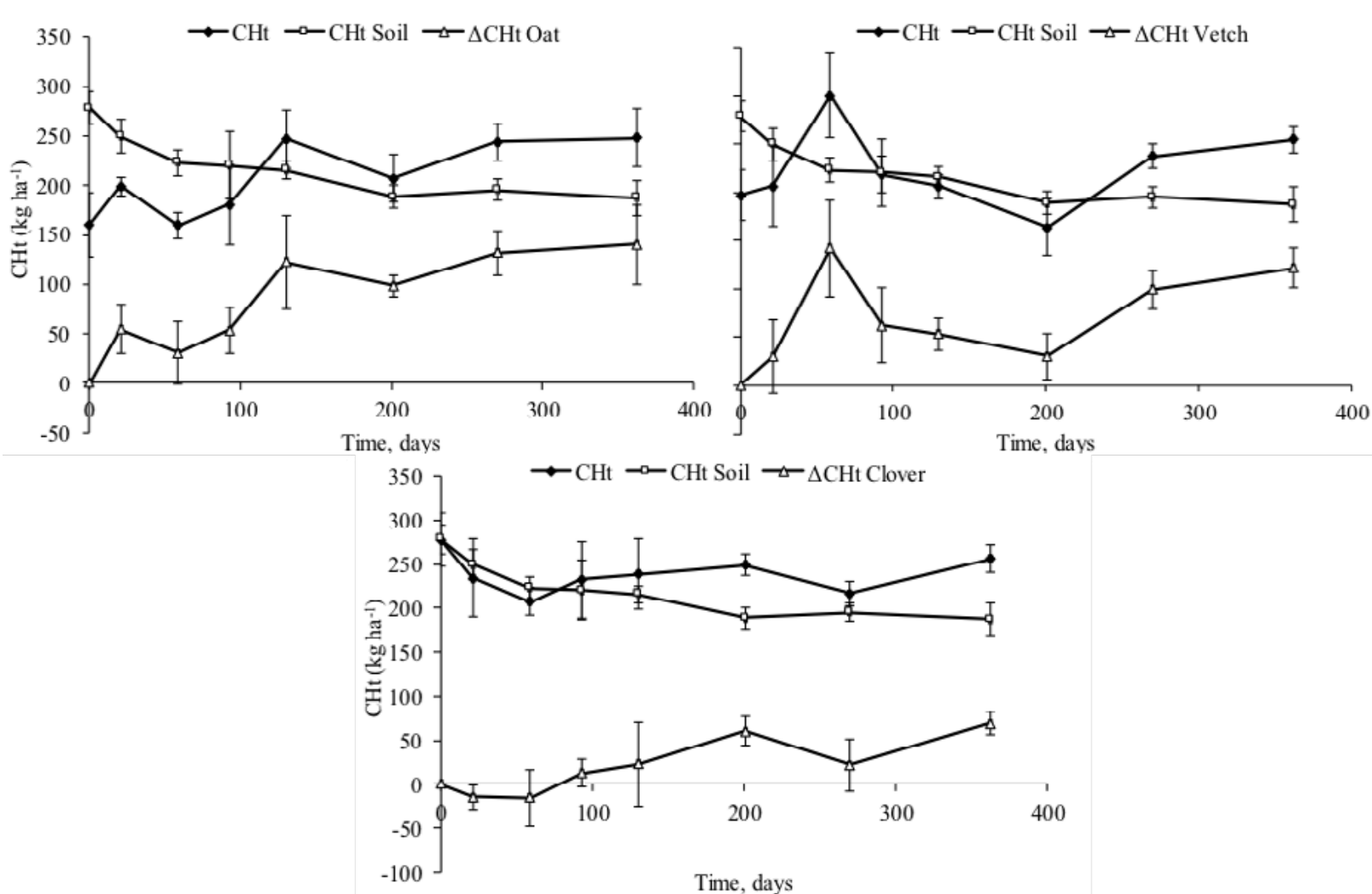

Figure 5. Dynamics of the content of total carbohydrates $\left(\mathrm{CHt}, \mathrm{kg} \mathrm{ha}^{-1}\right.$, ) at the $0-5 \mathrm{~cm}$ depth with different cover crops, initial residue $(\square)$ and cover crop input $(\Delta)$. The vertical bars represent \pm one standard deviation $(n=3)$.

\section{Conclusions}

The decomposition dynamics of CC can be described by a simple equation in the short term. Vetch residues initially showed a fast decomposition rate. They lost over 40\% DM in the first 21 days after being placed in incubation pots, this suggests an enhanced $\mathrm{N}$-availability in soil. Oat residues decomposed more slowly with a late partial release 3 to 4 months after the residues were addeed to the pots. Decomposition rates for oat, vetch and clover residues were different, with $\mathrm{k}$ values of $1.3,1.4$ and 1.9 year $^{-1}$, respectively.
Changes in soil labile carbon fractions were differentially influenced by residue quality over short periods of time. Lower POC concentrations in CC soils than in fallow soils indicated that, despite extra carbon input, the mineralization rate was much higher in $\mathrm{CC}$, thus affecting also native organic pools.

Soil $\mathrm{CHt}$ was influenced by residue quality, where the periods of greatest residue decay (vetch 21-59 days and oat 93-130 days) corresponded to higher soil $\mathrm{CHt}$. Hence, this organic carbon fraction is sensitive to residue decomposition and can be indicators of changes in soil organic matter over short periods of time. 
However, field studies are required to ascertain the effect of residue addition to soils and the transformation of the labile organic fractions (source and a sink of plant nutrients) for better understand the synchronization of nutrient release with crop requirements.

\section{REFERENCES}

- Acosta JA. 2009. Dinâmica do nitrogênio sob sistema plantio direto e parâmetros para o manejo da adubação nitrogenada no milho. Doctoral dissertation. Santa Maria, RS. Brasil: Universidade Federal de Santa Maria.

-Ambus P, Jensen ES. 1997. Nitrogen mineralization and denitrification as influenced by crop residue particle size. Plant Soil 197:261-270.

- Bastida F, Kandeler E, Moreno JL, Ros M, García C, Hernández T. 2008. Application of fresh and composted organic wastes modifies structure, size and activity of soil microbial community under semiarid climate. Appl Soil Ecol. 40:318-329.

- Bremner JM. 1996. Total Nitrogen. In: Sparks DL, editor. Methods of Soil Analysis. Part 3. Chemical Methods. Madison, WI: SSSA-ASA. p. 1085-1123.

- Carfagno PF, Eiza MJ, Quiroga A, Babinec F, Chagas C, Michelena R. 2013. Agua disponible en monocultivo de soja con cultivos de cobertura y barbechos reducidos en la Región Semiárida y Subhúmeda Pampeana. Ciencia del Suelo 31:67-81.

- Ćirić V, Belić M, Nešić L, Šeremešić S, Pejić B, Bezdan A, Manojlović M. 2016. The sensitivity of water extractable soil organic carbon fractions to land use in three soil types. Arch Agron Soil Sci. 62:1654-1664.

- Di Rienzo JÁ, Casanoves F, Balzarini MG, González L, Tablada M, Robledo CW. 2013. InfoStat. Grupo InfoStat, FCA, Universidad Nacional de Córdoba, Argentina.

- Douglas CL, Rickman RW. 1992. Estimating crop residue decomposition from air temperature, initial nitrogen content, and residue placement. Soil Sci Soc Am J. 56:272-278.

- Duval ME, Capurro JE, Galantini JA, Andriani JM. 2015. Utilización de cultivos de cobertura en monocultivo de soja: efectos sobre el balance hídrico y orgánico. Ciencia del Suelo 33:247-261.

- Duval ME, Galantini JA, Capurro JE, Martínez JM. 2016. Winter cover crops in soybean monoculture: Effects on soil organic carbon and its fractions. Soil Tillage Res. 161:95-105.
- Duval ME, Galantini JA, Iglesias JO, Canelo S, Martínez JM, Wall L. 2013. Analysis of organic fractions as indicators of soil quality under natural and cultivated systems. Soil Tillage Res. 131:11-19.

- Duval ME, Sá Pereira E de, Iglesias JO, Galantini JA. 2014. Efecto de uso y manejo de suelo sobres las fracciones de carbono orgánico en un Argiudol. Ciencia del Suelo 32:105-115

- Galantini JA, Senesi N, Brunetti G, Rosell R. 2004. Influence of texture on the nitrogen and sulphur status and organic matter quality and distribution in semiarid Pampean grassland soils. Geoderma 123:143-152.

- Ghani A, Dexter M, Perrott KW. 2003. Hot-water extractable carbon in soils: a sensitive measurement for determining impacts of fertilisation, grazing and cultivation. Soil Biol Biochem. 35:1231-1243.

- Hevia GG, Buschiazzo D, Hepper E, Urioste A, Antón E. 2003. Organic matter in size fractions of soils of the semiarid Argentina. Effects of climate, texture, management. Geoderma 116:265-277.

- Klute A. 1986. Water retention: laboratory methods. In: Klute A, editor. Methods of Soil Analysis: Part 1. Physical and mineralogical methods. Madison, WI: ASA and SSSA. p. 635-661.

- Kuo S, Sainju UM, Jellum EJ. 1997. Winter cover crop effects on soil organic carbon and carbohydrate in soil. Soil Sci Soc Am J. 61:145-152.

- Kuzyakov Y. 2010. Priming effects: interactions between living and dead organic matter. Soil Biol Biochem. 42:1363-1371

- Li Z, Zhao B, Zhang J. 2016. Effects of maize residue quality and soil water content on soil labile organic carbon fractions and microbial properties. Pedosphere 26:829838.

- Lupwayi NZ, Clayton GW, O'Donovan JT, Harker KN, Turkington TK, Rice WA. 2004. Decomposition of crop residues under conventional and zero tillage. Can J Soil Sci. 84:403-410.

- Mazzoncini M, Sapkota TB, Bàrberi P, Antichi D, Risaliti R. 2011. Long-term effect of tillage, nitrogen fertilization and cover crops on soil organic carbon and total nitrogen content. Soil Tillage Res. 114:165-174.

- Moraes Sá JC de, Lal R. 2009. Stratification ratio of soil organic matter pools as an indicator of carbon sequestration in a tillage chronosequence on a Brazilian Oxisol. Soil Tillage Res. 103:46-56.

- Moraes Sá JC de, Tivet F, Lal R, Briedis C, Hartan DC, dos Santos JZ, dos Santos JB. 2014. Long-term tillage systems impacts on soil $C$ dynamics, soil resilience and agronomic productivity of a Brazilian Oxisol. Soil Tillage Res. 136:38-50.

- Parton WJ, Silver WL, Burke IC, Grassens L, Harmon ME, Currie B, King JY. 2007. Global-scale similarities in nitrogen release patterns during long-term decomposition. Science 315:361-364. 
- Poeplau C, Don A. 2015. Carbon sequestration in agricultural soils via cultivation of cover crops-A metaanalysis. Agric Ecosyst Environ. 200:33-41.

- Puget P, Angers DA, Chenu C. 1999. Nature of carbohydrates associated with water-stable aggregates of two cultivated soils. Soil Biol Biochem. 31:55-63.

- Quemada M. 2005. Predicting crop residue decomposition using moisture adjusted time scales. Nutr Cycl Agroecosys. 70:283-291.

- Rasse D, Rumpel C, Dignac MF. 2005. Is soil carbon mostly root carbon? Mechanisms for a specific stabilisation. Plant Soil 269:341-356.

- Rimski-Korsakov H, Alvarez CR, Lavado RS. 2015. Cover crops in the agricultural systems of the Argentine Pampas. Journal of Soil and Water Conservation 70:134A-140A

- Sá Pereira E de, Galantini JA, Quiroga AR, Landriscini MR. 2014. Efecto de los cultivos de cobertura otoño invernales, sobre el rendimiento y acumulación de $\mathrm{N}$ en maíz en el sudoeste bonaerense. Ciencia del Suelo 32:219-231.

- Scholberg JM, Dogliotti S, Zotarelli L, Cherr CM, Leoni C, Rossing WA. 2010. Cover Crops in Agrosystems: Innovations and Applications. In: Lichtfouse E, editor. Sustainable Agriculture Reviews 4: Genetic engineering, biofertilisation, soil quality and organic farming. New York (NY): Springer. p. 59-98.

- Schomberg HH, Steiner JL, Unger PW. 1994. Decomposition and nitrogen dynamics of crop residues: residue quality and water effects. Soil Sci Soc Am J. 58:372-381.

- Soil Survey Staff. 2010. Keys to Soil Taxonomy. 11th ed. Washington (DC): USDA-Natural Resources Conservation Service. 365 p.

- Tian G, Brussaard L, Kang BT. 1995. An index for assessing the quality of plant residues and evaluating their effects on soil and crop in the (sub-) humid tropics. Appl Soil Ecol. 2:25-32.

- Van Soest PV, Robertson JB, Lewis BA. 1991. Methods for dietary fiber, neutral detergent fiber, and non-starch polysaccharides in relation to animal nutrition. J Dairy Sci. 74:3583-3597.

- Wander MM, Traina SJ. 1996. Organic fractions from organically and conventionally managed soils: I. Carbon and nitrogen distribution. Soil Sci Soc Am J. 60:10811087.

- Wang Q, Li Y, Alva A. 2010. Cropping systems to improve carbon sequestration for mitigation of climate change. J Environ Protec. 1:207-215. 